УДК 343.8

DOI https://doi.org/10.32837/yuv.v0i4.2220

\author{
Д. Пилипенко, \\ кандидат юридичних наук, \\ доцент кафедри кримінально-правових дисциплін \\ Криворізького навчально-наукового інституту \\ Донецького державного університету внутрішніх справ
}

\title{
ОЗНАКИ ТА ВИМОГИ СИСТЕМИ ПРИНЦИПІВ КРИМІНАЛЬНО-ВИКОНАВЧОГО ПРАВА
}

\begin{abstract}
Постановка проблеми. Процес удосконалення сфери галузевого права невід'ємно пов'язаний із оптимізацією як теоретичних, так і прикладних аспектів. Одним із напрямів цього процесу є з'ясування вже існуючих та вироблення нових теоретичних конструкцій щодо окремих положень теорії галузевого права з урахуванням умов сьогодення. Цей аспект насамперед стосується базисних теоретичних положень, покладених в основу будь-якої галузі права. Провідне місце серед цих положень посідають галузеві принципи. В умовах перманентного реформування внутрішньої державної системи протидії та боротьби зі злочинністю процес удосконалення положень галузевого права, що належить до цієї системи, набуває особливої актуальності. Одним із напрямів цього оптимізаційного процесу, безумовно, $€$ галузь кримінально-виконавчого права, яка регулює досить змістовний пласт правовідносин, пов'язаних зі сферою виконання i відбування кримінальних покарань. Ключовим аспектом, що потребує окремої уваги, $€$ система принципів кримінальновиконавчого права та відповідні іiі елементи, які фактично визначають ii зміст. У цьому контексті окремого теоретичного дослідження потребують ознаки й вимоги до системи принципів кримінально-виконавчого права, оскільки в теорії кримінальновиконавчого права визначені критеріі
\end{abstract}

переважно залишаються поза увагою науковців.

Оцінка стану літератури. Питання, пов'язані з визначенням ознак і вимог системи принципів кримінально-виконавчого права досліджувалися в роботах таких науковців, як О.М. Джужа, О.Г. Колб, О.М. Литвинов, А.А. Музика, А.Х. Степанюк, В.М. Трубников, В.П. Філонов, П.Л. Фріс, О.І. Фролов та інших.

Питання, пов'язані з визначенням ознак і вимог щодо системи принципів кримінально-виконавчого права, розглядаються науковцями не відокремлено та поверхнево, здебільшого в сукупності 3 іншими питаннями, пов'язаними 3 визначенням базових положень системи кримінально-виконавчого права.

Мета дослідження - визначення ознак і вимог до системи принципів кримінально-виконавчого права з урахуванням наявних теоретичних положень із цього питання.

Виклад основного матеріалу дослідження. Питання визначення ознак і вимог до системи принципів кримінально-виконавчого права $€$ майже не висвітленим вітчизняними науковцями, які здійснюють теоретичні дослідження у сфері виконання i відбування кримінальних покарань. Враховуючи це, з'ясування таких ключових критеріїв системи принципів кримінально-виконавчого

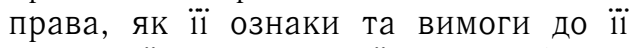
змістової конструкції, потребують 
окремого дослідження. Визначення таких критеріїв неодмінно впливатиме на формування сталих поглядів на змістовність системи принципів кримінально-виконавчого права та сприятиме подальшій належній реалізації груп принципів, які формують відповідну систему галузевих принципів кримінально-виконавчого права.

Відповідно до положень енциклопедичних словників система (від грецьк. system - ціле, складеність частин) є сукупністю елементів, які знаходяться у взаємовідносинах і взаємозв'язках і створюють відповідну цілісність та єдність [1, с. 835]. 3 погляду на філософію система ціле, створене 3 певних частин, що існують у взаємозв'язку [2, с. 210]. 3 приводу цього питання В.Д. Сорокін слушно зазначає, що система поєднує взаємодіючі елементи, які надають їй необхідні риси цілісності, інакше об'єкт виступає неорганізованою сукупністю [3, с. 182]. Зі свого боку О.В. Сумачьов до ознак системності відносить такі: неадитивність (принципова незвідність властивостей системи до суми властивостей іi складників); залежність кожного елемента системи від його місця, функцій усередині цілого; структурованість (система може бути описана тільки через іï структуру); взаємозалежність системи і середовища, в якому вона відіграє провідну роль; ієрархічність, яка припускає, що кожна система $є$ підсистемою і складається з підсистем [4, с. 51]. Екстраполюючи зазначені висновки щодо ознак системності на наявну систему принципів кримінально-виконавчого права, вважаємо за доцільне визначити характерні ознаки, що належать цій системі.

Ознака неадитивності як елемент системи є фактично невід'ємним іiі складником. Як зазначає Б.Г. Юдін, адитивність і неадитивність - це взаємопов'язані поняття наукового дискурсу, що виражають типи співвідношень між цілим і його складовими частинами, тобто між части- ною і цілим. Визначення адитивності часто висловлюють у вигляді «Ціле дорівнює сумі частин»; визначення не адитивності - у вигляді «Ціле більше суми частин» (суперадитивність), «Ціле менше суми частин» (субадитивність). Автор підкреслює, що адитивність $€$ характерною для матеріальних об'єктів та зазначає, що маса фізичної системи дорівнює сумі мас частин системи. Проте, вказує науковець, таке явище як суспільство характеризується цілою низкою особливостей, які неможливо пояснити, виходячи із властивостей окремих індивідів [5]. За нашим переконанням, для системи принципів кримінально-виконавчого права характерною є саме ознака адитивності, а не навпаки.

Одним із ключових аспектів існування системи кримінально-виконавчого права є застосування інтеграційного підходу до визначення сутності принципів кримінально-виконавчого права у вигляді поєднання природно-правової та позитивістської концепцій. Це, відповідно, передбачає врахування всіх наявних в теорії уявлень про змістовний складник засад цієї галузі права. Цей аспект так само дозволяє визначити систему принципів, яка повною мірою відповідатиме сучасним соціальним та юридичним уявленням про засадничу систематику цієї галузі права. Отже, визначена на підставі інтеграційного підходу система принципів кримінально-виконавчого права повною мірою відображатиме конструкцію, що будується на відповідних іï елементах та не виходить за їні межі. Іншими словами, існуюча структурована система принципів кримінально-виконавчого права фактично унеможливлює наявність у ї змісті факторів суперадитивності або субадитивності, які є елементами неадитивності. Отже, ми вважаємо, що саме адитивність $є$ однією з ознак системи принципів кримінально-виконавчого права.

Наступною ознакою, яка також $€$ актуальною для визначення 
системи принципів кримінально-виконавчого права, є залежність кожного елемента системи від його місця. Дійсно, належність принципів до кожної із груп, які визначають систему принципів, передбачає його певну фіксованість та умовну залежність. Вважаємо, що у цьому аспекті недоцільно говорити про певний імператив конекції засади з відповідною групою принципів. Згаданий вище інтеграційний підхід передбачає не лише кореляційний взаємозв'язок груп принципів однієї системи, але й взаємозв'язок принципів різних груп між собою. У цьому аспекті, за нашим переконанням, показовою може бути дихотомія загальноправових принципів у групах галузевих і міжгалузевих принципів і зворотній синтезуючий процес формування загально-правового (загально-соціального) принципу на основі результатів реалізації похідних галузевих засад. Ми вважаємо, що «адикція» принципів до відповідної групи не $€$ аксіоматичною, тому для системи принципів кримінально-виконавчого права характерною $є$ саме ознака умовної групової залежності принципів. Оскільки тут йдеться про внутрішньогрупову структурну залежність елементів, доцільно цю ознаку визначити як умовну структурну адиктивність.

Черговою ознакою системи принципів кримінально-виконавчого права $€$ ï структурованість. Визначення системи принципів кримінальновиконавчого права крізь призму іiі структурної реалізації $€$ фактором виокремлення відповідних груп, які містять правові засади за відповідними ознаками. Водночас слід наголосити на тому, що структурна реалізація системи принципів кримінально-виконавчого права $€$ сталою моделлю сприйняття системи принципів цієї галузі права як єдиного та цілісного комплексу груп принципів, покладених в основу функціонування всієї системи кримінальновиконавчого права.
Окремою ознакою системи принципів кримінально-виконавчого права є взаємозалежність цієї системи та середовища, в якому вона відіграє провідну роль. Вище ми висловлювали авторську позицію щодо умовної залежності принципів від відповідних груп. Проте цей фактор не спрацьовує у випадку визначення ознаки взаємозалежності системи принципів від відповідного середовища. За таких умов система принципів кримінальновиконавчого права $є$ цілком «адиктивна» від сфери суспільних відносин, в основу яких вона вбудована як один із ключових іï елементів. Отже, принципи кримінально-виконавчого права $€$ характерними для внутрішньодержавної системи виконання і відбування кримінальних покарань та фактично не існують за ії межами. Проте із цього правила є одне виключення. Слід наголосити, що така група принципів, як загально-правові, є комплексом засад, характерним та визначальним для будь-якої галузі права, який може існувати відособлено та поза межами галузі права. Проте використана група загально-правових принципів у межах окремої галузі права може корегуватися в умовах кореляціï зі зміною внутрішньодержавного вектору відповідної політики та/або суспільного ставлення чи сприйняття щодо сутнісних характеристик окремої сфери відносин. Враховуючи вказане, цей критерій системи принципів кримінально-виконавчого права слід визначити як ознаку внутрішньогалузевої залежності.

Іерархічність як ознака системи принципів кримінально-виконавчого права є критерієм, що відображає структурну будову системи засад. Відповідно до ієрархічності ї послідовність визначена шляхом дедукції, тобто від загального до окремого. Саме дедукція, як ми вважаємо, у цьому сенсі демонструє коректне сприйняття ієрархічності як обов'язкової ознаки системи кримінально-виконавчого права. Проте серед науковців наявність 
цієї ознаки принципів не завжди сприймається схвально. О. П. Кучинська, досліджуючи цей аспект у теоpiï кримінального процесу, зазначає, що будь-які спроби виділити той чи інший принцип або групу принципів як головні, домінуючі або визначальні порівняно з іншими елементами системи не мають під собою достатнього підгрунтя. Допустивши можливість нерівнозначності принципів кримінального провадження, невідворотно слід визнати, що, по-перше, певні принципи мають більш «принциповий» характер, аніж інші, по-друге, єдиною системою однойменних елементів (кримінальних процесуальних принципів) об'єднані різні за змістом явища. Однак процесуальне положення, що має ціннісну вагу, нижчу за інші, не може входити до системи рівновеликих структур [6, с. 148]. У цьому сенсі О.П. Кучинська цілком погоджується з Ю.М. Грошевим, який вважає зазначену класифікацію формальною, «оскільки такий їхній поділ штучно виокремлює конституційні принципи як головні, тоді як інші є другорядними. Принципи $€$ найбільш узагальненими нормами, оскільки вони однаковою мірою важливі, незалежно від правового вираження та діапазону їх дії, а також тісно пов'язані між собою і мають однакову юридичну силу» [7, с. 53].

За нашим переконанням, такі висновки поважних науковців щодо ознаки ієрархічності принципів права обумовлені буквальним сприйняттям ознаки ієрархічності та визначення iï щодо структури принципів як певного імперативного критерію, за яким система принципів сприймається за схемою «провідний - другорядний». На нашу думку, ознака ієрархічності $€$ номінальною під час визначення системи принципів кримінально-виконавчого права, отже, критерії від загального та окремого визначають лише макет подальшої конструкції системи принципів. У фактичному, прикладному сенсі ієрархічність не повинна сприйматись як догма, що фіксує чітко визначену пріоритетність певної групи принципів як основи для кримінально-виконавчої регуляції. За цих умов визначення принципів як відповідної основи правовідносин відбувається без обов'язкового окреслення групової належності, оскільки прикладний фактор існування принципів передбачає одночасне комплексне ї застосування. Тому у цьому аспекті ознака ієрархічності $€$ шаблонним фактором, позбавленим фактичного змісту. Отже, за прикладним аспектом існування принципи кримінальновиконавчого права $є$ рівнозначними, однак за іхнім походженням вони не завжди є рівнозначними. Це правило $€$ характерним для правових механізмів, які передбачають одночасне застосування як загально-правових принципів, так і принципів окремих інститутів галузевого права.

Враховуючи перераховані ознаки системи принципів кримінально-виконавчого права, додатково слід виокремити певні вимоги, на основі яких ця система повинна грунтуватися. Ці вимоги є критеріями, що належать до системи принципів кримінально-виконавчого права як єдиного цілісного явища. Досліджуючи це теоретичне питання, Р.X. Якупов стверджує, що система принципів повинна будуватися на підставі певних вимог: адекватності, цілісності, повноти, несуперечливості та незалежності [8, с. 54].

Ми вважаємо, що більшість із зазначених вимог є актуальними й для сфери кримінально-виконавчого права. Тому далі ми детально визначимо вимоги системи принципів кримінально-виконавчого права. Вимога адекватності системи принципів поєднує якісні та кількісні критерії системи принципів. Згідно з цією вимогою існуючі систематизовані принципи за своїми змістовними і множинними складниками відповідають наявній системі кримінальновиконавчого права. Тобто наявна сучасна модель системи принципів як 
певна частина цілком збігається 3 конструкцією загальноприйнятної, конвенціональної моделі існування сфери кримінально-виконавчого права.

Вимога холістичності (цілісності) передбачає наявність сталих i дієвих зв'язків між елементами системи принципів кримінальновиконавчого права, що забезпечує стабільність іi існування у визначеній системі. В системі принципів кримінально-виконавчого права це означає наявність відповідного генетичного зв'язку та постійної кореляції між собою груп засад, які складають систему принципів кримінально-виконавчого права. Така цілісна система має бути «гнучкою» і додатково наділятися критерієм стабільності, який забезпечуватиме сталість і стійкість системи принципів за умов зміни зовнішньої кон'юнктури, тобто факторів, які існують поза межами цієї системи та можуть суттєво вплинути на іiі існування. Отже, за умов зміни парадигми внутрішньодержавного сприйняття сфери виконання і відбування кримінальних покарань або зміни суспільних уявлень щодо цієї сфери діяльності система принципів кримінально-виконавчого права також зазнаватиме певних коливань, проте дотримана вимога цілісності забезпечуватиме іiі стабільність в умовах певних реформаторських видозмін.

Вимога повноти відображає певну завершеність, необхідну наповненість системи відповідними групами принципів, що зі свого боку обумовлює наявність необхідної і достатньої кількості принципів у кожній із груп цієї системи. Дотримання такої вимоги гарантуватиме абсолютність відповідності системи принципів кримінальновиконавчого права внутрішньодержавній діяльності у сфері виконання і відбування кримінальних покарань.

Вимога несуперечливості системи принципів кримінально-виконавчого права за своїм спрямуванням тяжіє до вже згаданої вимоги цілісності. Несуперечливість як вимога забезпечує відсутність суттєвих та / або критичних протиріч усередині системи принципів, що може негативно вплинути на їхню реалізацію або існування всієї системи загалом. Тому фактор генетичного зв'язку між принципами та їхн індивідуальна і групова узгодженість $є$ фактичним гарантом дотримання вимоги несуперечливості самої системи принципів кримінально-виконавчого права.

Наступною вимогою, яка, на нашу думку, є актуальною для формування та існування системи принципів кримінально-виконавчого права, є вимога автономності. Запропонована вище P.X. Якуповим вимога незалежності, за нашим переконанням, етимологічно не повною мірою відповідає змісту системи принципів кримінально-виконавчого права. Попри відокремленість між собою за змістом та груповою належністю, всі принципи, що формують одну систему, комплексно задіються в механізмі іхньої реалізації, оскільки фактор дієвості правового механізму, в основі якого вони містяться, пропорційно залежить від кількісної та якісної характеристики принципів, що одночасно визначають цей механізм. Поодинока реалізація принципів кримінально-виконавчого права або відокремлена реалізація однієї із груп системи цих принципів унеможливлюється сутнісною характеристикою самої системи, яка, як ми вже зазначали, є відображенням інтеграційного підходу, тобто симбіозом природно-правової та позитивістської концепцій. Саме така поєднана модель утворює систему принципів, які у своєму сукупному поєднанні забезпечують належне функціонування внутрішнього правового механізму галузі кримінально-виконавчого права. Водночас фактор автономності $€$ характерним для груп принципів, що формують систему, відповідно до якої на основі кожної із груп можуть утворюватися додаткові підгрупи. Зокрема, в межах кримінально-виконавчого права на основі принципів 
відповідних інститутів можуть засновуватися засади окремих субінститутів. Така сутність системи кримінально-виконавчого права, як ми вбачаємо, відповідає вимозі автономності.

Черговою вимогою, яка, на наше переконання, висувається до системи принципів кримінально-виконавчого права, - це вимога транспарентності. Ознаки відкритості та прозорості як безумовних складників вимоги транспарентності існування системи принципів кримінально-виконавчого права передбачають взаємодію 3 іншими аналогічними системами принципів інших галузей права, 3 якими галузь кримінально-виконавчого права перекликається у прикладній сфері. Зокрема, галузь кримінальновиконавчого права під час реалізації внутрішніх правових механізмів тісно пов'язана з галузями кримінального права і процесу. Крім того, багатоаспектність існування галузі кримінально-виконавчого права передбачає iii співіснування з галуззю цивільного права, зокрема з іï напрямками, що визначають соціальну сферу (сімейні відносини, сфера пенсійного забезпечення тощо). Враховуючи це, вимога транспарентності підтримуватиме актуальність та, відповідно, дієвість системи принципів кримінально-виконавчого права. Визначена вимога транспарентності зумовлює актуальність існування останньої.

У цьому списку вимог є вимоги амеліорації. Ця вимога спрямована на постійне вдосконалення існуючої системи принципів кримінальновиконавчого права, на іï оптимізацію. Цей процес відбувається за рахунок декількох явищ. По-перше, фактором удосконалення можуть бути відповідні нові теоретичні та прикладні надбання всередині самої системи кримінально-виконавчого права. По-друге, за рахунок запозичення досвіду інших систем, згаданих під час розгляду вимоги транспарентності. Амеліорація (вдосконалення, покра- щення) також фактично сприяє забезпеченню життєдіяльності системи принципів кримінально-виконавчого права та своєчасності іï реагування задля забезпечення пристосованості до нових умов з урахуванням відповідних якісних змін у суспільному житті, державній політиці тощо.

\section{Висновки i перспективи} подальших досліджень. Система принципів кримінально-виконавчого права як і будь-яка система, сформована в межах галузевого права, наділена комплексом критеріїв, що визначають ї̈ сутність. Одними з таких критеріїв, безумовно, є ознаки системи принципів кримінально-виконавчого права та вимоги, яким ця система має відповідати та на яких грунтуватись як єдиний цілісний об'єкт. Запропонований у межах цієї статті авторський перелік ознак і вимог є відображенням суб'єктивної точки зору автора щодо цих складників системи кримінально-виконавчих принципів та цілком може створити передумови щодо подальших дискусій щодо цього питання. Подальші наукові дослідження у цьому напрямку матимуть суттєвий вплив на формування сталих теоретичних позицій стосовно існування системи принципів кримінально-виконавчого права загалом, вироблення конкретизованих теоретичних переконань стосовно окремих критеріїв цієї системи, до яких, безумовно, належать ознаки системи принципів кримінально-виконавчого права та вимоги, на яких ця система має грунтуватись.

У статті досліджено питання визначення ознак системи приницпів кримінально-виконавчого права та вимог, на яких ияя система має грунтуватися та яким фактично має відповідати. Розглянуто теоретичні позиціі щцодо відокремлення ключових ознак системи принциипів кримінально-виконавчого права. Запропоновано авторський погляд на перелік ознак визначеної 
системи принципів. Наголошено, що до ключових ознак системи принципів кримінально-виконавчого права належать адитивність, умовна структурна адиктивність, структурованість, внутрішньогалузева залежність, ієрархічність. Адитивність як ознака системи приниипів окреслюе єдність системи кримінально-виконавчих принцииів. За цјєю ознакою така система сприймається як єдиний неподільний об'єкт, який відображає набір певних елементів, груп тощо. Ознака умовної структурної адиктивності передбачає певну залежність принципів від відповідної групової приналежності, а також умовну взаємозалежність окремих груп. Умовна залежність обумовлена рухомістю та функціональністю принципів $i$ груп принциипів, щцо призводить до постійної взаємодії між собою в умовах внутрішніх кореляційних зв'язків. Ознака структурованості передбачає сприйняття системи принципів кримінально-виконавчого права як єӘиного об'єкта, який комплексно складається з окремих груп принциипів. Ці групи відображають набір засад, які визначають основу для інститутів та/або субінститутів галузі. Внутрішньогалузева залежність передбачає адикиію система принйиів від галузі ї походження. За межами галузі як провідного об'єкта система принципів є нікчемною. Ознака ієрархічності демонструє векторність походження принципів від загально-правових до позитивістських засад. Водночас ия ознака не впливає на сприйняття принципів за їньою значущістю. Крім того, до системи принципів висуваються вимоги холістичності, повноти, несуперечливості, автономності, транспарентності, амеліорації.

Ключові слова: ознаки системи принципів кримінально-виконавчого права, вимоги до системи принципів, адитивність, структурованість, ієрархічність, холістичність, транспарентність.

Pylypenko D. Symbols and requirements of systems principles of criminal and executive law

The article examines the question of defining the features of the system of principles of criminal executive law and the requirements on which this system should be based and which, in fact, must meet. Theoretical positions on the separation of key features of the system of principles of criminal executive law are considered. The author's view on the list of features of a certain system of principles is offered. It is emphasized that the key features of the system of principles of criminal executive law include: additivity, conditional structural addiction, structure, intra-industry dependence, hierarchy. Additivity as a feature of the system of principles outlines the unity of the system of principles of criminal executive. On this basis, the system of principles is perceived as a single indivisible object, which reflects a se't of certain elements, groups, and so on. The sign of conditional structural addiction implies a certain dependence of the principles on the corresponding group affiliation, as well as the conditional dependence of individual groups in relation to each other. Conditional dependence is due to the mobility and functionality of principles and groups of principles, which leads to constant interaction with each other in terms of internal correlations. The sign of structure implies the perception of the system of principles of criminal executive law as a single object, which consists of separate groups of principles. These groups represent a set of principles that define the basis for institutions and/or subinstitutions of the industry. Intraindustry dependence involves the addition of a system of principles 
from the field of its origin. Outside the industry as a leading entity, the system of principles is insignificant. The sign of hierarchy demonstrates the vector origin of principles from general law to positivist principles. However, this feature does not affect the perception of the principles of their significance. Also, the system of principles has requirements: holistic, complete, consistent, autonomy, transparency, amelioration.

Key words: features of the system of principles of criminal executive law, requirements to the system of principles, additivity, structure, hierarchy, holism, transparency.

\section{Література}

1. Прохоров А.М. Советский энииклопедический словар. 3-е изд. Москва: «Советская энциклопедия», 1984. 1600 c.
2. Закомлистов А.Ф. Юридическая философия : учеб. Пособие. СПб. : Изд-во Юридический центр Пресс, 2003. 548 с.

3. Сорокин В.Д. Право и время: правовая система и переходное время. Правоведение. 2002. № 1. С. 180-190.

4. Сумачев А.В. Публичность и диспозитивность в уголовном праве. Москва : Издательская группа «Юрист», 2003. $331 \mathrm{c}$.

5. Юдин Б.Г. Аддитивность и неаддитивность. URL: https://gtmarket.ru/ concepts / 7243

6. Кучинська О.П. Роль принцииів кримінального провадження в механізмі забезпечення прав його учасників : дис. ... д-ра юрид. наук : 12.00.09. Київ, 2013. $441 \mathrm{c}$.

7. Грошевий Ю.М, Капліна О.В. Кримінальний процес : підручник. Харків : Право, 2010. 608 с.

8. Якупов Р.Х. Уголовнай процеес : учебник для вузов. Москва : «Зерияало», 1998. $448 \mathrm{c}$. 